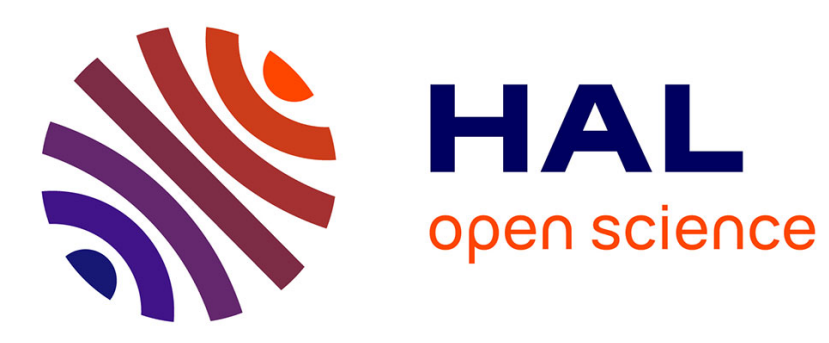

\title{
Do formulas reduce political influence on intergovernmental grants? Evidence from Tanzania
}

\author{
Maarten A Allers, Lewis J Ishemoi
}

\section{To cite this version:}

Maarten A Allers, Lewis J Ishemoi. Do formulas reduce political influence on intergovernmental grants? Evidence from Tanzania. The Journal of Development Studies, 2011, 47 (12), pp.1781-1797. 10.1080/00220388.2011.598512 . hal-00759560

\section{HAL Id: hal-00759560 https://hal.science/hal-00759560}

Submitted on 1 Dec 2012

HAL is a multi-disciplinary open access archive for the deposit and dissemination of scientific research documents, whether they are published or not. The documents may come from teaching and research institutions in France or abroad, or from public or private research centers.
L'archive ouverte pluridisciplinaire HAL, est destinée au dépôt et à la diffusion de documents scientifiques de niveau recherche, publiés ou non, émanant des établissements d'enseignement et de recherche français ou étrangers, des laboratoires publics ou privés. 


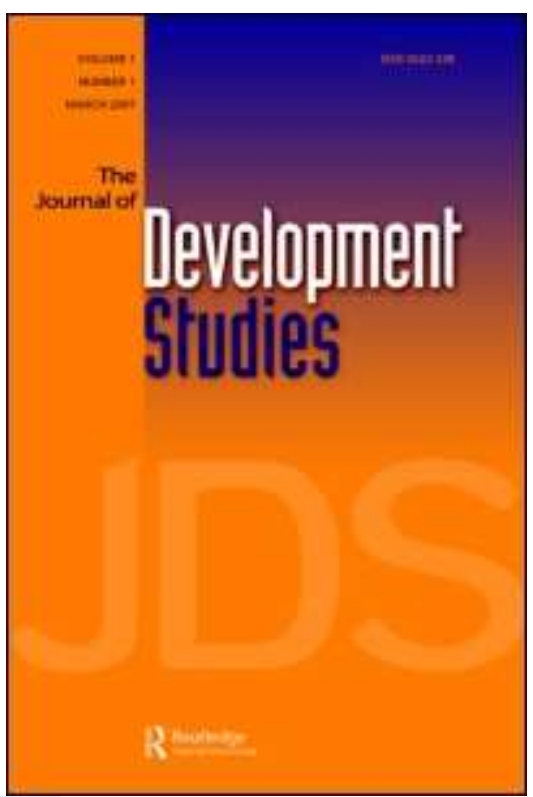

\section{Do formulas reduce political influence on intergovernmental grants? Evidence from Tanzania}

\begin{tabular}{|r|l|}
\hline Journal: & Journal of Development Studies \\
\hline Manuscript ID: & FJDS-2010-Sep-0038.R1 \\
\hline Manuscript Type: & Original Manuscripts \\
\hline Keywords: & $\begin{array}{l}\text { Economics < Economics, Africa < Geographical Area, Democracy < } \\
\text { Government, State Policy, \& Ideologies, Government < } \\
\text { Government, State Policy, \& Ideologies, Policy < Government, } \\
\text { State Policy, \& Ideologies, Service delivery < Government, State } \\
\text { Policy, \& Ideologies }\end{array}$ \\
\hline
\end{tabular}

\section{SCHOLARONE Manuscripts}




\title{
Do formulas reduce political influence on intergovernmental grants? Evidence from Tanzania
}

\begin{abstract}
Subnational governments usually depend on the central government for a large share of their revenues. Therefore, a fair allocation of intergovernmental grants is essential for financing vital local services like education and healthcare. In Tanzania, and many other countries, regions that are better represented in the national parliament receive significantly more funds than others. Recently, Tanzania replaced the previously existing discretionary method of grant allocation by allocation formulas. We study whether this has reduced the effect of malapportionment on grant allocation. Surprisingly, we find that formula allocation does not significantly change this effect. This has important policy implications.
\end{abstract}

\section{Introduction}

In most countries, tax revenues are predominantly generated at the central government level, while subnational governments are responsible for providing many public services. In order for subnational governments to be able to finance service provision, this vertical balance must be addressed. The obvious solution is the introduction of intergovernmental grants, which exist in many countries (Boadway, 2001). Grants allocation may be based on spending need, revenue capacity, or both. Thus, intergovernmental grants may help reduce fiscal disparities among subnational governments (Ladd and Yinger, 1994).

However, in practice, grant allocation is the result of a bargaining process between competing interests. Each region tries to secure a big slice of the cake. Politicians deciding over grant allocation try to consolidate or increase their power base. A growing number of studies documents political influence on the regional distribution of government spending in general, and on grant allocation in particular. ${ }^{1}$ A common conclusion is that regions which are overrepresented in the national parliament, which decides on grant allocation, seem to receive disproportionally large grants (for example, Ansolabehere et al., 2003; Knight, 2008; Dragu and Rodden, 2010).

Some countries have one electoral district only: the entire nation. Many countries, however, have district systems in operation, where every district elects one or more 
members of parliament. Often, some districts are better represented than others, that is, the number of seats per 1,000 voters may vary between electoral districts. In countries where this is the case, local governments in electoral districts that are well represented at the national level are often found to receive more grants per capita.

However, the connection between political representation and grant allocation is not entirely straightforward. The seminal model of Baron and Ferejohn (1989) is ambiguous about the outcome: under certain circumstances, a negative relation is possible. That is because better representation strengthens a region's power to make proposals, but it may make it a less attractive coalition partner. Dragu and Rodden (2010), however, present a model in which an increase in representation always leads to a more favourable share of the pie.

The mounting empirical evidence of a positive relationship between representation and grant revenues raises the question whether institutional arrangements can be used to solve this problem. Obviously, making representation more equal would be the best solution. However, malapportionment is not easily reduced, as this would end the political careers of many MPs who would have to vote for such a change. Other options should therefore be explored as well. These would of course also reduce incumbent politicians' power, but in a much more limited way.

In some countries, allocation of intergovernmental transfers is the responsibility of an independent non-partisan agency. Khemani (2007) reports that, in India, delegating grant allocation to an independent commission seems to have reduced political influence. However, in India, malapportionment is not the problem, representation being rather equally distributed over regions. Political influence in India takes the form of allocating grants to states ruled by the parties which form the national government.

We look at a more limited option: introducing formulas for grant allocation. Of course, a formula may still favour some regions over others for political reasons, but it is more difficult to do so than without a formula. Moreover, it is easier to spot. Tanzania recently introduced grant allocation formulas which are based on experts' opinions concerning regional spending needs. In Tanzania, representation is distributed quite unevenly across subnational governments. We empirically investigate whether the relationship between representation and grant allocation was affected by the introduction of grant allocation formulas. To the best of our knowledge, such a study has not been done before. The second contribution of this 
paper is that, as far as we know, the effect of representation on grant allocation has not been studied before in a low-income country.

We find that the effect of representation on grant allocation in Tanzania is strong compared with the effects reported in studies of other countries. We conclude that formula allocation did nothing to help reduce the strong effect of representation on the grants received by subnational governments. That is because politicians have the power to overrule the formulas. We conclude that formula-based allocation without an independent body making legally binding recommendations for grant allocation is no recipe for ending the effect of malapportionment on grants.

The next section sketches the institutional background by presenting some basic facts about local government, intergovernmental grants and politics in Tanzania. Then, the setup of the empirical analysis is discussed, and the results are offered. This is followed by a discussion with policy recommendations, and by the conclusions.

\section{Institutional background}

\section{Local governments and their revenues}

There are two levels of government in Tanzania mainland: the central government, and 114 districts or local governments (in 2002). ${ }^{2}$ The 21 regions do not form a separate government level; these are deconcentrated departments of the central government. The islands community of Zanzibar has a high degree of autonomy and is not included in this study. Local Government Authorities (LGAs) ${ }^{3}$ in Tanzania mainly depend on grants from the central government to finance public service provision. Own revenues cover less than 10 per cent of expenditures (URT, 2007).

The intergovernmental transfer system includes recurrent block grants targeted at five priority areas: education, health, water, agriculture, and roads. The health grant and (especially) the education grant are the largest block grants to LGAs. A sixth type of recurrent grant is the general purpose grant, which was introduced to compensate districts for the loss of tax revenue following the abolishment of several local taxes. Apart from the six types of recurrent grants, there are capital development grants. These are meant to help funding capital expenditures. Finally, LGAs receive earmarked ministerial subventions and grants from basket funds.

Prior to fiscal year 2003/2004, grant allocation was ad hoc and discretionary. Local governments were essentially treated like central government agencies in the 
budgeting process (URT, 2004). Local governments requested budgets from the central government. These requests were scrutinised and vetted by representatives of the President's Office - Public Service Management (PO-RALG) and sectoral ministries. The Ministry of Finance was responsible for reconciling local government requests with available resources. This approach limited local autonomy and resulted in an uneven allocation of resources.

Tanzania's Local Government Reform Programme commissioned a study of options to improve grant allocation. Better grant allocation is part of a more general drive at decentralization in Tanzania. The study was conducted by a research team from the Andrew Young School of Policy Studies, headed by Jamie Boex, and funded by the Danish government. Based on this study (LGRP, 2003), Cabinet decided in February 2004 to introduce a formula-based allocation system of block grants. Allocation formulas were created by the Local Government Finance Working Team, based on the recommendations of the study and on consultations with stakeholders. Formulas reflect differences in spending needs, ${ }^{4}$ but not differences in revenue capacity (Allers and Ishemoi, 2010). For practical reasons, implementation was staggered across several years. Allocation formulas were introduced in 2004/2005 for education and health block grants; in 2005/2006 for the three remaining sectoral block grants (water, agriculture and roads); in 2006/2007 for capital development grants, and in 2007/2008 for the general purpose grant (URT, 2004; URT, 2005b; URT, 2006; URT, 2008). Formulas for ministerial subventions and basket funds were introduced between 2004/2005 and 2008/2009.

Although formulas now exist for the allocation of intergovernmental grants, adherence to these formulas is limited. Districts that would receive a lower grant as a result of the introduction of a formula are held harmless, that is, their grants are topped up to prevent them from receiving fewer resources than the previous year. Applying such a hold-harmless rule means that it takes a few years before every LGA receives the formula-based grant amount. In practice, however, districts that are being held harmless frequently receive more resources than they received the year before. This is because the central government frequently approves new establishments to be created by LGAs, and the funding of the wage costs associated with these establishments, without taking into account the allocation formulas (LGRP, 2007). As a result, convergence to the formula based grants does not occur. In 2007/2008, all LGAs were in fact being held harmless (URT, 2007). 
In practice, establishing the formula-funded amount for each LGA is just the first step in determining the grant it will receive. Holding harmless is the second step, and, after that, Parliament may approve additional funds (LGRP, 2007). As a result, the introduction of allocation formulas has not taken away control over grant allocation from politicians completely. The question now is whether political influence has been reduced after the introduction of the formulas.

\section{Politics}

As grants to LGAs are approved by Parliament, any political influence on intergovernmental grants is therefore likely to be related to the parliamentary elections, which are held every five years. The first multiparty parliamentary elections in Tanzania took place in 1995. Until then, Tanzania had a single party system run by the Chama Cha Mapinduzi (CCM) party, which is still by far the most powerful political party. There is universal adult suffrage. Every LGA consists of one, two or three constituencies. In the parliamentary elections, every constituency elects one Member of Parliament by a first-past-the-post system. ${ }^{5}$ The number of constituencies in a district is not proportional to its population. As a result, there is a considerable variation across LGAs in per capita representation in Parliament. The 456,000 inhabitants of Bukombe and the 47,000 inhabitants of Mafia, for example, both have one representative in Parliament.

There is considerable variation between districts in voter turnout and the vote share of the CCM party in the 2005 parliamentary elections. Turnout ranged from 53 per cent in Mwanza to 92 per cent in Newala. The vote share of the CCM ranged from 32 per cent (Kibondo) to 97 per cent (Makete). However, the CCM has little to fear from opposition parties. In nine constituencies, the CCM ran unopposed. Only 8 constituencies elected an MP from a different party (14 in the parliamentary elections of 2000). This suggests that political rivalry is not played out, in the first place, between different parties, but within the CCM party itself. Politicians wanting to become an MP will try to secure the position of CCM candidate in their constituency. MPs who want to be re-elected (there is no term limit in Tanzania) need to make sure they remain the CCM candidate. This gives them a strong incentive to strive for higher grants aimed at the LGA in which their constituency is located. 


\section{Empirical analysis}

\section{Political influence on grant allocation}

The model of Dragu and Rodden (2010) predicts a positive relationship between representation and LGA grant revenues. Such a relationship has been found in many countries. Thus, we expect to find it in Tanzania as well. Our aim is to investigate whether formula allocation reduces the effect of representation on grant revenue. We expect that the introduction of allocation formulas reduces the politicians' power to influence grants allocation. Therefore, we hypothesise that the introduction of formulas reduces the effect of malapportionment on grants.

The strength of this effect may be expected to depend on political accountability. That is because, if elected politicians are more accountable to their constituencies, they have a stronger incentive to influence policy decisions in favour of their constituencies. A likely indicator of political pressure on MPs is voter turnout. Therefore, we control for regional differences in voter turnout.

We also control for a different possible effect of politics on grant allocation. Possibly, LGAs where the ruling CCM party is strong will receive a larger per capita grant than other LGAs. This might be the case if politicians from the ruling party reward voters for their vote, while they punish districts where many people vote for opposition parties. Several studies found such an effect in other countries (See Khemani, 2007, and the references therein). However, because the CCM party has little reason to feel threatened by other parties, such an effect seems less likely in Tanzania.

\section{Specification and data}

In order to be able to compare results for different grants and for different years, per capita grant amounts for LGAs are expressed relative to their average value. Following Ansolabehere et al. (2002), this was done by dividing the per capita value of a particular grant to a particular LGA by the mean per capita value of that grant. Thus, a relative per capita grant of 1.12, for example, represents a per capita grant which is 12 per cent above the average per capita grant. Grants included in this study are the five sectoral block grants (education, health, water, agriculture and roads), the general purpose grant, subventions and basket funds, and the development grant. Because the block grants for the sectors water, agriculture and roads are rather small, we combine these ("Other sector grants"). 
We measure relative representation in a similar way, by dividing the number of constituencies (or MPs) per inhabitant by the national average of that ratio. ${ }^{6}$ As an example, consider Mafia, which had a relative representation of 4.53 in the 2005 parliamentary elections. This means that each inhabitant of this LGA was represented by 4.5 times as many MPs as the average citizen of Tanzania.

The model to be estimated is

$G_{i}=P_{i} \alpha+X_{i} \beta+\varepsilon_{i}$,

where $G$ is the relative per capita grant under study, $P$ is a vector of political variables, $X$ is a vector of control variables, $\alpha$ and $\beta$ are parameters to be estimated, and $\varepsilon$ is the error term. The index $i$ is used to denote LGAs. The model is estimated using cross-sectional data. As representation hardly varies over time, and many control variables are unavailable for different periods, we cannot use a panel analysis. ${ }^{7}$ The model is estimated for two different fiscal years: 2002/2003 and 2007/2008. The first fiscal year dates from the period before grant allocation formulas. The second fiscal year is the most recent one for which grant data exist. In 2007/2008, allocation formulas existed for most grants to LGAs.

As discussed above, $P$ consists of three political variables: the share of the CCM party, voter turnout, and relative political representation. For the analysis of grant allocation in 2002/2003, we use political characteristics from the 2000 parliamentary elections. For the analysis of grant allocation in 2007/2008, we use political characteristics from the parliamentary elections in 2005. This effectively rules out a possible reverse causality between grants and politics.

As control variables we include every variable that is used in any of the allocation formulas for sectoral block grants, the general purpose grant or the capital development grant. ${ }^{8}$ In addition, we include the number of inhabitants, to control for the possibility that grant allocation takes into account economies or diseconomies of scale, and a dummy variable that indicates whether a LGA is classified as urban. Boex (2003) found that urban LGAs received relatively high grants in 2002/2003. Table 1 lists the variables included, their definition, their descriptive statistics and their data sources. 
$<$ Table 1 about here $>$

Many of the control variables we include are correlated with each other. The resulting multicollinearity makes it difficult to assess the exact extent to which the control variables influence grant allocation. We take this in our stride, as our interest lies in the effect of political characteristics. As some control variables are rather strongly correlated with, for example, political representation, we need to include them. Leaving them out would risk attributing possible effects of other variables to political characteristics.

In 2005 and in 2007, several new LGAs were created by splitting existing ones. As data on some variables is only available for the LGAs that existed in 2002, we treated the LGAs that were split as if they were still intact in 2007. We did this by adding up grant amounts, number of inhabitants, etc., of LGAs that used to be one jurisdiction in 2002 but were split after that year. As a result, we have data on 112 LGAs. $^{9}$

\section{Results}

\section{Fiscal year 2007/2008}

We start by estimating the model for fiscal year 2007/2008, the most recent year for which we have data. Of the three political characteristics we include in our analysis, two turn out not to have any impact on grant allocation. Voter turnout and the vote share for the ruling party do not significantly influence the allocation of any of the existing intergovernmental grants in Tanzania. This is not surprising, as the CCM party is so strong that party affiliation of LGAs is not really an issue. Whether or not an LGA is one of the few to elect MPs from an opposition party does not play a role, and neither does the proportion of the electorate that votes. Because the ruling party has no reason to feel threatened, there is no need to punish LGAs that support the opposition.

As the effect of both voter turnout and the share of the ruling party are completely insignificant in 2007/2008, these variables can safely be left out from the rest of the analysis. We have two reasons for doing this. First, for six LGAs, voter turnout in the 2005 parliamentary elections is not available, resulting in fewer observations available for analysis. That is because in one or more constituencies in those LGAs, only one party fielded a candidate, who was elected automatically. We prefer not to leave out 
$<$ figure 1 about here>

In contrast with voter turnout or the vote share of the ruling party, political representation seems to have a considerable influence on per capita grant revenues of LGAs. Figure 1 provides a graphical impression of the relationship between relative representation and the relative share in total intergovernmental transfers to LGAs. The Figure shows a strong correlation with a tight fit. Similar relationships, although with a less tight fit, exist between representation and individual grants. Controlling for other determinants, we estimate strong and statistically significant effects of representation on grant allocation. Only in the case of subventions and basket funds, no such effect seems to exist. See Table 2.

$<$ Table 2 about here $>$

According to the allocation formula, the education grant should be allocated based on the number of school-aged children. The coefficient for this variable is indeed significantly positive, but it is obvious that other variables play a role as well. LGAs where a high share of the population does not have access to piped water receive a lower education grant, as do LGAs with a large rural population and a large area relative to the number of inhabitants. LGAs with relatively many villages receive a large education grant.

LGAs where many people lack access to piped water receive a low health grant. Even more remarkably, under-five mortality, an indicator of health spending need, and one of the variables in the health grant allocation formula, is not related to the health grant received by LGAs. It should be kept in mind, however, that lack of significance may 
result from the fact that many of the control variables are collated to some extent. The share of poor residents, also included in the allocation formula, has no significant effect on the health grant either. The third variable in the allocation formula, the length of the route regularly travelled by medical vehicles, is only weakly related to health grant revenue. Health grants are positively related to the number of villages and negatively to the size of the rural population.

Other sector grants, meant to finance spending on water supply, agriculture and roads, are positively related to the length of the route regularly travelled by medical vehicles and to the number of villages. These grants are negatively related to the size of the rural population and to the area relative to the population. The general purpose grant is higher for LGAs with many villages, as is should be, because this is one of the elements of the allocation formula. The number of rural residents, which is also represented in the formula, has no impact on actual grant allocation. Subventions and basket funds, an amalgamate of different grants, are higher for LGAs where a large share of the population lacks access to piped water. These are likely to be jurisdictions which are backward in other respects too, so this should not come as a surprise. Finally, development grants are higher for LGAs with a more extensive road network. Generally, LGAs with many poor residents do not seem to receive higher grants. Also, grants to urban LGAs generally do not differ from grants to non-urban LGAs. Boex (2003) reaches a different conclusion, but this study concerns fiscal year 2002/2003, which precedes formula allocation.

$<$ Figure 2 about here $>$

Figure 2 compares the coefficients of political representation and their 95-\% confidence intervals from Table 2 for the different types of intergovernmental grants. Political influence is relatively small but significant in the case of education grants. For health grants, the effect of representation is stronger, but not significantly so. For other sector grants, general purpose grants and development grants, political influence is significantly stronger than for education grants. In 2007/2008, only the general purpose grant and some of the subventions and baskets funds did not yet have formulas. Interestingly, in these cases, political influence is not significantly stronger than for grants for which formulas have been introduced. No effect of formulas on political influence is apparent from Figure 2. 


\section{Before formula introduction: Fiscal year 2002/2003}

In order to explore whether the introduction of allocation formulas has reduced the impact of malapportionment on grant allocation, we compare regression results for fiscal year 2007/2008 with those for fiscal year 2002/2003. For 2002/2003, grant data are available for the five sectoral block grants. For the general purpose grant, for subventions and basket funds and for the development grant, no comparison between $2007 / 2008$ and 2002/2003 is possible. In 2002/2003, no allocation formulas were introduced yet, while in 2007/2008, formulas had been introduced for all sectoral block grants.

Table 3 displays regression results for 2002/2003. The effect of relative political representation on relative grant revenues is significant for all sector grants. Like in $2007 / 2008$, the effect is relatively small for education grants. Of the other variables, lack of access to piped water, number of children and number of villages have a significant effect on education grants in 2002/2003, as they have in 2007/2008 However, rural population and land do not influence education grants in 2002/2003, as they do in $2007 / 2008$.

$<$ Table 3 about here>

We cannot confirm Boex's (2003) conclusion that grant allocation in Tanzania was pro-urban in 2002/2003. The coefficient of the urban variable is insignificant in the case of education and health grants, and negative for other sector grants. The difference between our findings and those of Boex may be explained by the fact that we include political representation in our regressions, and that we use more control variables.

Like in 2007/2008, number of villages and rural population influence health grants in $2002 / 2003$, but, unlike in $2007 / 2008$, lack of access to piped water is not related to health grants. In 2002/2003, LGAs with a poor population received more other sector grants. In 2007/2008, this is no longer the case.

$<$ Figure 3 about here $>$ 
Figure 3 compares our coefficient estimates of the effect of representation on grant revenues for 2002/2003 with those for 2007/2008. The Figure shows clearly that the effect of political representation on the allocation of the sectoral block grants did not disappear after the introduction of the allocation formulas. The coefficient estimates are hardly lower after the introduction of formulas, and the confidence intervals in Figure 3 clearly show that these changes are far from significant at the 95-per cent confidence level.

Apart from being statistically significant, the effect of representation on grant allocation is surprisingly strong. A shift in representation of one standard deviation is associated with a per capita grant which is, in 2007/2008, 8 per cent higher in case of the education grant, 25 per cent higher in case of the health grant, and even 52 per cent higher in case of the capital development grant. Total transfers to an LGA are, on average, 26 per cent (or 0.65 standard deviation) higher when representation is increased by one standard deviation. These are strong effects, both in absolute terms and compared with previous estimates for other countries. ${ }^{12}$ In fact, preliminary results indicating even somewhat stronger effects were the reason that we included some additional control variables that are correlated to political representation. As a result, the coefficients of representation and their t-values decreased slightly, but they remained significant for all but one grant category (subventions and basket funds).

\section{Discussion}

One obvious way to address the problem of malapportionment would be to change the boundaries of constituencies to better represent their population size. Using our regression estimates, we can estimate the effects this would have on the allocation of intergovernmental grants. In the case where every LGA would have exactly the same representation, the most underrepresented LGA, Bukombe, would see total transfers increase by 31 per cent (rightmost bar in Figure 4). On the other end of the spectrum, Mafia would lose no less than 53 per cent of present grant revenues (leftmost bar in Figure 4). Overall, about 80 billion Tanzanian shillings would be shifted away from LGAs that are currently overrepresented to LGAs that are underrepresented.

Malapportionment is likely to affect more policy areas apart from intergovernmental grants. Therefore, a more equal representation would be highly desirable for Tanzania. Although this goal is not easily reached, it is feasible, as the United States have shown (Ansolabehere et al., 2002). In fact, removing malapportionment could be 
less difficult in Tanzania than in other countries, because, in Tanzania, one party (CCM) dominates government at all levels. Proposals to change the system would not lead to a conflict between different parties.

A less ambitious solution could be the introduction of an independent body overseeing grant allocation. Khemani (2007) documents that such a commission is successful in India. In that country, intergovernmental grants administered by the Planning Commission, a government agency with political representation, are shown to be politically influenced. However, this political bias is neutralised by grants allocated by the independent Finance Commission. The Finance Commission seems to take the bias in the Planning Commission grants into account, with the result that total grant allocation shows no political bias. Thus, it is not necessary to bring all intergovernmental grants under the responsibility of an independent agency, as long as such an agency controls a big enough share of total grants. Like in India, the recommendations of the independent agency should be legally binding. The central government or other government bodies should not be able to override its recommendations in any way. Presently, adherence to the allocation formulas cannot be enforced in Tanzania.

$<$ Figure 4 about here $>$

\section{Conclusion}

There is growing evidence that regional differences in political representation results in an unequal allocation of intergovernmental grants. Regions which are better represented in the national parliament generally receive higher grants. We show that this is also the case in Tanzania. Total intergovernmental transfers are, on average, 26 per cent higher when representation is increased by one standard deviation.

We investigate whether the introduction of grant allocation formulas might reduce political influence on grants. In Tanzania, grants were allocated discretionary until, recently, allocation formulas were introduced. Allocation formulas may still favour some regions for political reasons, but this is more difficult than without formulas. Moreover, formulas increase transparency. In the case of Tanzania, where the central government depends heavily on European donors to finance its budget, allocation formulas cannot be blatantly unfair. 
We compare the effect of representation on grant allocation before (2002/2003) and after (2007/2008) the introduction of formulas. Remarkably, we must conclude that the introduction of formulas has done nothing to change this effect. Moreover, the grants which still did not have formulas in 2007/2008 do not show more political influence than the grants allocated by formulas.

The reason is not that the formulas are politically influenced. The problem is that actual grant allocation is not ruled by the formulas. Politicians do not need to influence allocation formulas, they simply override them.

We conclude that the introduction of allocation formulas as such does not help curb political influence on grant allocation. Allocation formulas must be decided on by an independent body, and, above all, they must be legally binding. Here, India has set an example that Tanzania may want to follow. However, this will require some pressure on the politicians who must approve the necessary changes. They are not likely to give up power spontaneously.

Of course, setting up an independent grant allocation body would be a second best solution. Putting an end to malapportionment would be preferable, although perhaps more difficult to implement. As malapportionment may be expected to influence political decisions apart from grant allocation, a more equal representation would be highly desirable for Tanzania.

\section{References}

Allers, M.A. and Ishemoi L.J. (2010) Fiscal Capacity Equalisation in Tanzania. Local Government Studies, 36, pp. 697-713.

Allers, M.A. and Ishemoi L.J. (2011) Equalising sub-national governments' spending needs in a developing country: the case of Tanzania, unpublished paper.

Ansolabehere, S., Gerber, A. and Snyder, J. (2002) Equal Votes, Equal Money: CourtOrdered Redistricting and Public Expenditures in the American States. American Political Science Review, 96, pp. 767-777.

Baron, D.P. and Ferejohn, J.A. (1989) Bargaining in Legislatures, American Political Science Review, 83, pp. 1181-1206.

Boadway, R. (2001) Inter-Governmental Fiscal Relations: The Facilitator of Fiscal Decentralization, Constitutional Political Economy, 12, pp. 93-121.

Boex, J. (2003) The incidence of local government allocations in Tanzania, Public Administration and Development, 23, pp. 381-391. 
Dragu, T. and Rodden, J. (2010) Representation and regional redistribution in federations, Working paper, Institut d'Economia de Barcelona, Barcelona.

Ishemoi, L.J. (2011) Fiscal Disparities and Intergovernmental Transfers in Tanzania, Groningen: University of Groningen.

Khemani, S. (2007) Does delegation of fiscal policy to an independent agency make a difference? Evidence from intergovernmental transfers in India, Journal of Development Economics, 82, pp. 464-484.

Knight, B. (2008) Legislative representation, bargaining power and the distribution of federal funds: evidence from the U.S. congress, The Economic Journal, 118, pp. 1785-1803.

Ladd, H.F. and, Yinger, J. (1994) The case for equalizing aid, National Tax Journal, 47, pp. 211-224.

LGRP (Local Government Reform Programme) (2003) Final Report: Developing a System of Intergovernmental Grants in Tanzania.

LGRP (2007) Adherence to The Formula-Based Recurrent Block Grant System and The Allocation of Personal Emoluments in Tanzania.

National Electoral Commission of Tanzania (2000) Parliamentary election results 2000 (Dar es Salaam: Government Printers).

URT (United Republic of Tanzania) (2005a) Poverty and Human Development Report (Dar Es Salaam: Mkuki na Nyota Publishers).

URT (2005b) Local Government Fiscal Review 2005 (Dar Es Salaam: Government Printers).

URT (2006) Local Government Fiscal Review 2006 (Dar Es Salaam: Government Printers).

URT (2007) Local Government Fiscal Review 2007 (Dar Es Salaam: Government Printers).

URT (2008) Guidelines for the preparation of local government authorities' medium term plans and budgets for 2008/09 to 2010/11 (Dodoma: PMO-RALG). 


\section{Notes}

${ }^{1}$ For an overview of the literature, see Dragu and Rodden (2010).
${ }^{2}$ More on the institutional background may be found in Ishemoi (2011).
${ }^{3}$ The paper uses the terms LGAs and districts interchangeably to mean all jurisdictions governed by Municipal, Town and District Councils in Tanzania.

${ }^{4}$ Allers and Ishemoi (2011) argue that the formulas are not based on a thorough study of LGA's spending needs, and present a method to derive formulas which better reflect differences in spending needs.

${ }^{5}$ Apart from the 232 MPs elected by constituencies, Parliament consists of 75 special seats for women, five members appointed by the Zanzibar House of Representatives, ten members appointed by the President, and the Attorney General.

${ }^{6}$ Alternatively, representation could be defined based on the number of constituencies per registered voter. Unfortunately, the number of registered voters per LGA is not available for the 2000 parliamentary elections. Using this definition in our regressions for fiscal year 2007-2008 hardly affects the results, however.

${ }^{7}$ Some previous work relies on cross-sections (for example, Knight, 2008), while others (for example, Khemani, 2007) use panel data. Ansolabehere et al. (2002) use both, and find almost the same result in both cases.

${ }^{8}$ The formulas can be found in URT (2006), page 34. For two variables, under-five mortality and number of poor residents, grant allocation formulas use regional data, not data at LGA level. We use data at the LGA level instead.

${ }^{9}$ In 2002, there were 114 districts, but one of these is Dar es Salaam city council, which consists of three different districts which are included in our analysis. For one other district, we have insufficient data.

${ }^{10}$ The vote share of every party is available per constituency for the 2000 parliamentary elections, but as the number of registered voters per constituency is not available, the vote share in LGAs consisting of more than one constituency cannot be calculated.

11 The correlation between relative representation and voter turnout is 0.22 ; between relative representation and the share of the CCM party the correlation is -0.07 .

${ }^{12}$ Because results are presented in different ways in different studies, they are not always easy to compare. Ansolabehere et al. (2002, Table 2) found a coefficient for relative representation of 0.17 , which is lower than our coefficient of 0.37 (Table 2, Total transfers). Dragu and Rodden (2010) report that one standard deviation increase in representation produces a 0.35 standard deviation increase in grants share per capita; our estimate is 0.65 . Thus, it seems that our estimates are twice as high as those of previous studies. It should be noted, however, that Tanzania is a unitary state, and a low income country. Previous work has focused on federations and on medium and high income countries. Ansolabehere et al. (2002) and most other studies in the field focus on the United States. Dragu and Rodden (2010) is a multi-country study (Argentina, Australia, Brazil, Canada, Germany, Mexico, Spain, Switzerland, USA). 
Table 1. Variable definitions, descriptive statistics, and sources

\begin{tabular}{|c|c|c|c|c|c|c|}
\hline Variable & Definition & $\begin{array}{l}\text { Mean } \\
2002 / 2003\end{array}$ & $\begin{array}{l}\text { Standard } \\
\text { deviation } \\
\text { 2002/2003 }\end{array}$ & $\begin{array}{l}\text { Mean } \\
2007 / 2008\end{array}$ & $\begin{array}{l}\text { Standard } \\
\text { deviation } \\
2007 / 2008\end{array}$ & Source \\
\hline Education grant & Per capita education block grant to LGA, divided by average per capita amount & 1.11 & 0.38 & 1.05 & 0.30 & $\mathrm{~A}$ \\
\hline Health grant & Per capita health block grant to LGA, divided by average per capita amount & 1.22 & 0.66 & 1.12 & 0.60 & A \\
\hline Other sector grants & $\begin{array}{l}\text { Per capita block grants for water, roads and agriculture to LGA, divided by } \\
\text { average amount }\end{array}$ & 1.28 & 1.01 & 1.23 & 0.93 & A \\
\hline General purpose grant & Per capita general purpose grant to LGA, divided by average per capita amount & n.a. & & 1.18 & 0.72 & A \\
\hline $\begin{array}{l}\text { Subvention and basket } \\
\text { funds }\end{array}$ & $\begin{array}{l}\text { Per capita amount of ministerial subventions and basket fund grants to LGA, } \\
\text { divided by average per capita amount }\end{array}$ & n.a. & & 1.16 & 0.87 & A \\
\hline $\begin{array}{l}\text { Capital development } \\
\text { grant }\end{array}$ & $\begin{array}{l}\text { Per capita amount of capital development grants to LGA, divided by average per } \\
\text { capita amount }\end{array}$ & n.a. & & 1.17 & 0.73 & A \\
\hline Total transfers & Per capita grants listed above, divided by average per capita amount & n.a. & & 1.12 & 0.40 & A \\
\hline CCM share & Vote share of CCM party in previous parliamentary election & n.a. & & 0.72 & 0.14 & $\mathrm{~B}$ \\
\hline Turnout & Voter turnout in previous parliamentary election (share of registered voters) & n.a. & & 0.74 & 0.07 & $\mathrm{~B}$ \\
\hline Representation & Number of constituencies per one million inhabitants in parliamentary election & 7.06 & 4.04 & 5.78 & 3.29 & $\mathrm{~B}$ \\
\hline No piped water & Share of population without access to piped water & 0.47 & 0.29 & 0.41 & 0.25 & $\mathrm{C}$ \\
\hline Poor & Share of population below the poverty line, 2002 & 0.34 & 0.12 & 0.34 & 0.12 & $\mathrm{D}$ \\
\hline Medical vehicle route & Length of road regularly travelled by medical vehicles, $\mathrm{km}$ per inhabitant & 0.019 & 0.017 & 0.015 & 0.015 & $\mathrm{C}$ \\
\hline Under-five mortality & Under-five mortality rate (per live birth), 2002 & 0.15 & 0.04 & 0.15 & 0.04 & $\mathrm{D}$ \\
\hline Children & Share of school-aged children in total population, 2002 & 0.19 & 0.02 & 0.19 & 0.02 & $\mathrm{C}$ \\
\hline Villages & Number of villages per 1,000 inhabitants & 0.35 & 0.18 & 0.30 & 0.16 & $\mathrm{C}$ \\
\hline Rural population & Share of rural population & 0.77 & 0.28 & 0.76 & 0.28 & $\mathrm{C}$ \\
\hline Land & Land area $\left(\mathrm{km}^{2}\right)$ per inhabitant & 0.023 & 0.019 & 0.020 & 0.016 & $\mathrm{C}$ \\
\hline Road length & Road length $(\mathrm{km})$ per inhabitant & 0.0028 & 0.0020 & 0.0024 & 0.0017 & $\mathrm{C}$ \\
\hline Population & Number of inhabitants (millions) & 0.29 & 0.17 & 0.34 & 0.20 & $\mathrm{C}$ \\
\hline Urban & Dummy variable that takes the value one if the LGA is classified as "urban" & 0.19 & 0.39 & 0.19 & 0.39 & $\mathrm{E}$ \\
\hline
\end{tabular}

Sources:

A Grants: website of Local Government Finance Working Group (www.logintanzania.net). Population: C.

B For 2005: website of the National Electoral Commission of Tanzania (http://www.nec.go.tz). For 2000: National Electoral Commission of Tanzania (2000).

C Database used to calculate formula-based grant amounts, made available to us by Jameson Boex.

D URT (2005a).

E Derived from the LGA's vote code (a unique numeric identifier). The third digit of this code is 2 for urban LGAs and 3 for rural ones 
Table 2. Regression results 2007/2008

\begin{tabular}{|c|c|c|c|c|c|c|c|c|c|c|c|c|c|c|}
\hline \multirow[b]{2}{*}{ Representation } & \multicolumn{2}{|c|}{ Education grant } & \multicolumn{2}{|c|}{ Health grant } & \multicolumn{2}{|c|}{ Other sector grants } & \multicolumn{2}{|c|}{$\begin{array}{c}\text { General purpose } \\
\text { grant }\end{array}$} & \multicolumn{2}{|c|}{$\begin{array}{c}\text { Subventions \& } \\
\text { basket funds }\end{array}$} & \multicolumn{2}{|c|}{ Development grant } & \multicolumn{2}{|c|}{ Total transfers } \\
\hline & 0.11 & $(2.39)$ & 0.36 & $(4.29)$ & 0.59 & $(4.96)$ & 0.63 & $(6.01)$ & 0.02 & $(0.14)$ & 0.75 & $(8.40)$ & 0.37 & (9.10) \\
\hline No piped water & -0.30 & $(2.59)$ & -0.51 & $(2.42)$ & -0.21 & $(0.70)$ & 0.14 & $(0.54)$ & 0.95 & $(2.39)$ & -0.002 & $(0.01)$ & -0.07 & $(0.73)$ \\
\hline Poor & -0.28 & $(1.25)$ & 0.23 & $(0.57)$ & 0.18 & $(0.32)$ & -0.19 & $(0.38)$ & -1.04 & $(1.34)$ & -0.33 & $(0.74)$ & -0.29 & $(1.44)$ \\
\hline Medical vehicle route & 1.61 & $(0.60)$ & 8.80 & $(1.82)$ & 18.08 & $(2.63)$ & 3.75 & $(0.63)$ & 9.82 & $(1.07)$ & -0.82 & $(0.16)$ & 3.30 & $(1.40)$ \\
\hline Under-five mortality & -0.30 & $(0.46)$ & 0.40 & $(0.35)$ & -0.16 & $(0.10)$ & -2.73 & $(1.89)$ & 1.51 & $(0.68)$ & 1.42 & $(1.15)$ & 0.26 & $(0.46)$ \\
\hline Children & 7.32 & $(3.96)$ & 6.36 & $(1.92)$ & 7.56 & $(1.61)$ & -4.17 & $(1.01)$ & 3.53 & $(0.56)$ & -6.26 & $(1.77)$ & 2.01 & (1.24) \\
\hline Villages & 0.71 & $(2.56)$ & 1.09 & $(2.21)$ & 1.43 & $(2.03)$ & 1.37 & $(2.24)$ & 0.92 & $(0.98)$ & -0.98 & $(1.86)$ & 0.37 & (1.51) \\
\hline Rural population & -0.54 & $(2.02)$ & -1.15 & $(2.39)$ & -1.62 & $(2.37)$ & 0.20 & $(0.33)$ & 0.21 & $(0.23)$ & 0.43 & $(0.85)$ & -0.23 & $(0.99)$ \\
\hline Land & -4.31 & $(2.30)$ & -5.78 & $(1.72)$ & -10.58 & $(2.21)$ & 1.77 & $(0.42)$ & 3.14 & $(0.49)$ & -0.85 & $(0.24)$ & -2.49 & $(1.51)$ \\
\hline Road length & 0.91 & $(0.03)$ & 57.20 & $(1.19)$ & 46.68 & $(0.68)$ & -116.63 & (1.96) & 33.93 & $(0.37)$ & 134.25 & $(2.63)$ & 40.91 & (1.74) \\
\hline Population & -0.12 & $(0.77)$ & 0.31 & $(1.10)$ & 0.02 & $(0.06)$ & -0.28 & $(0.80)$ & -0.54 & $(1.01)$ & 0.31 & (1.04) & 0.002 & $(0.01)$ \\
\hline Urban & -0.24 & $(1.28)$ & -0.53 & $(1.58)$ & -0.91 & $(1.91)$ & 0.72 & (1.74) & 1.03 & $(1.62)$ & -0.07 & $(0.21)$ & -0.05 & $(0.28)$ \\
\hline Constant & 0.14 & $(0.34)$ & -0.07 & $(0.09)$ & -0.07 & $(0.07)$ & 1.20 & $(1.33)$ & -0.53 & $(0.38)$ & 0.91 & $(1.16)$ & 0.35 & $(0.98)$ \\
\hline $\mathrm{R}^{2}$ & \multicolumn{2}{|c|}{0.38} & \multicolumn{2}{|c|}{0.51} & \multicolumn{2}{|c|}{0.59} & \multicolumn{2}{|c|}{0.49} & \multicolumn{2}{|c|}{0.16} & \multicolumn{2}{|c|}{0.63} & \multicolumn{2}{|c|}{0.74} \\
\hline
\end{tabular}

$\mathrm{N}=112$. Absolute t-values within parentheses. Dependent variable is per capita grant divided by mean per capita grant. 
Table 3. Regression results 2002/2003

\begin{tabular}{|c|c|c|c|c|}
\hline & Education grant & Health grant & Other sec & tor grants \\
\hline Representation & $0.13(2.45)$ & $0.53 \quad(7.17)$ & 0.81 & (6.38) \\
\hline No piped water & $-0.30(2.58)$ & $-0.17 \quad(1.09)$ & -0.34 & $(1.25)$ \\
\hline Poor & $-0.31(1.15)$ & $0.27 \quad(0.75)$ & 1.22 & (1.99) \\
\hline Medical vehicle route & $3.07(1.10)$ & $1.72(0.45)$ & -11.01 & $(1.71)$ \\
\hline Under-five mortality & $-1.32(1.75)$ & $-1.28 \quad(1.26)$ & -0.88 & $(0.51)$ \\
\hline Children & $4.98 \quad(2.32)$ & 3.99 (1.38) & 1.02 & $(0.21)$ \\
\hline Villages & $1.13(3.98)$ & $1.14 \quad(2.99)$ & 0.95 & $(1.47)$ \\
\hline Rural population & $-0.36(1.11)$ & -1.20 & -1.61 & $(2.18)$ \\
\hline Land & $-2.62(1.37)$ & $-3.99 \quad(1.55)$ & -1.49 & $(0.34)$ \\
\hline Road length & $-42.77(1.68)$ & 35.39 & 206.05 & $(3.52)$ \\
\hline Population & $-0.63(2.87)$ & $-0.37 \quad(1.26)$ & 0.13 & $(0.26)$ \\
\hline Urban & $0.04(0.18)$ & $-0.28 \quad(0.91)$ & -1.14 & (2.14) \\
\hline Constant & $0.62(1.26)$ & $0.63 \quad(0.95)$ & 0.71 & $(0.63)$ \\
\hline $\mathrm{R}^{2}$ & 0.49 & 0.69 & 0. & 52 \\
\hline
\end{tabular}


Figure 1. Relative share of LGAs in total intergovernmental transfers versus relative political representation, 2007/2008

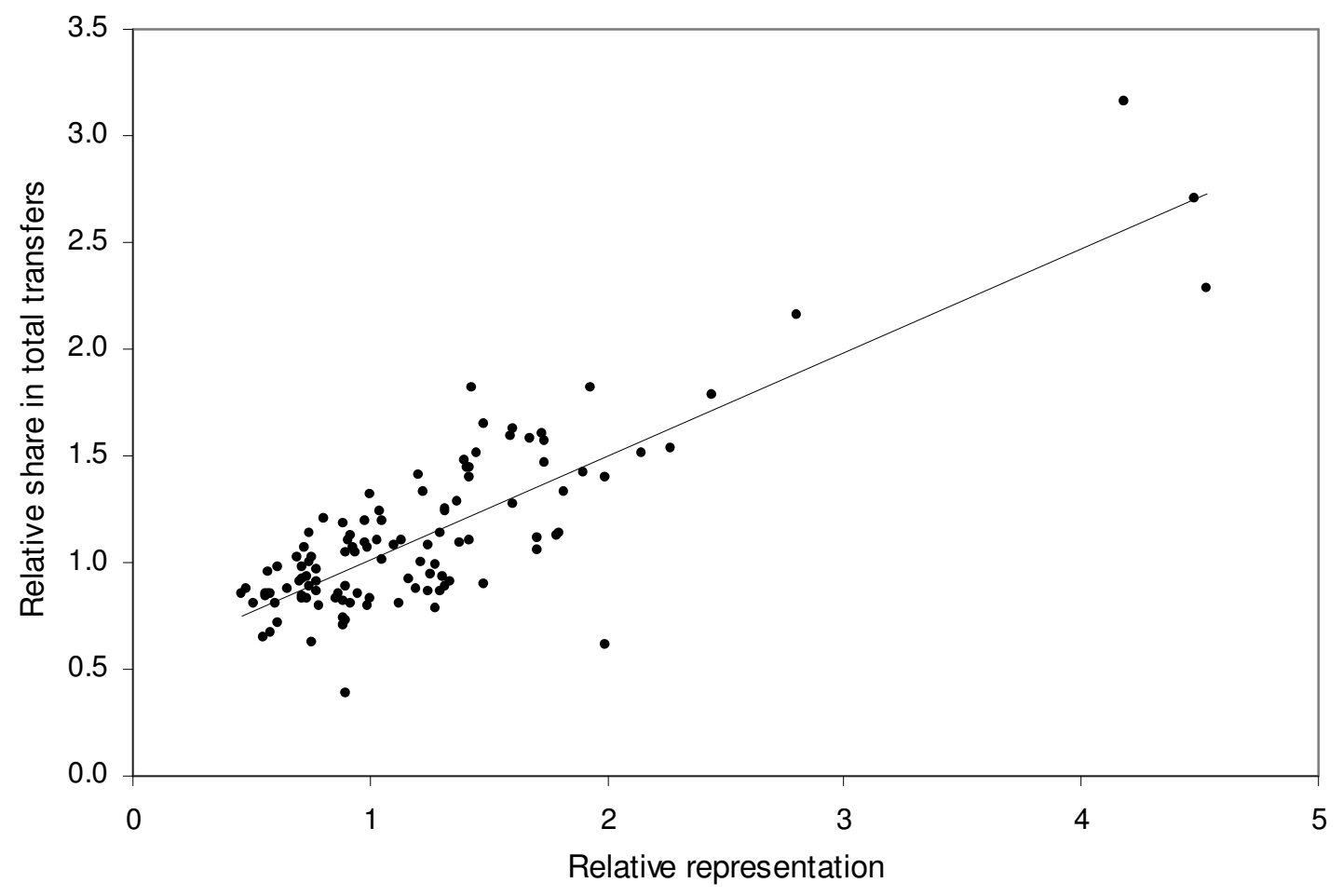


Figure 2. Coefficient estimates of the effect of political representation on grant allocation and their 95-percent confidence intervals: different grants compared (2007/2008)

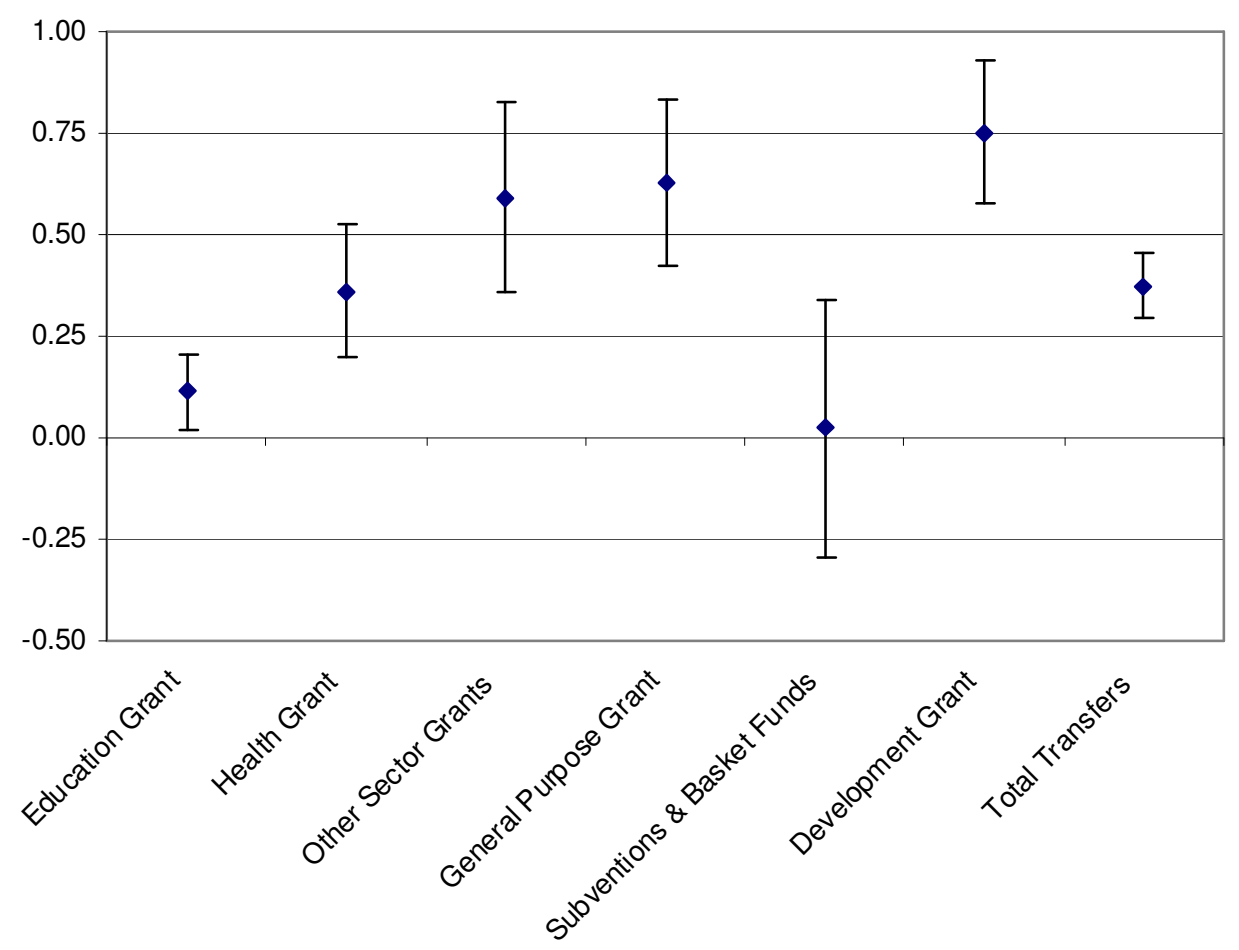


Figure 3. Coefficient estimates of the effect of political representation on grant allocation and their 95-percent confidence intervals: comparison of 2002/2003 with $2007 / 2008$

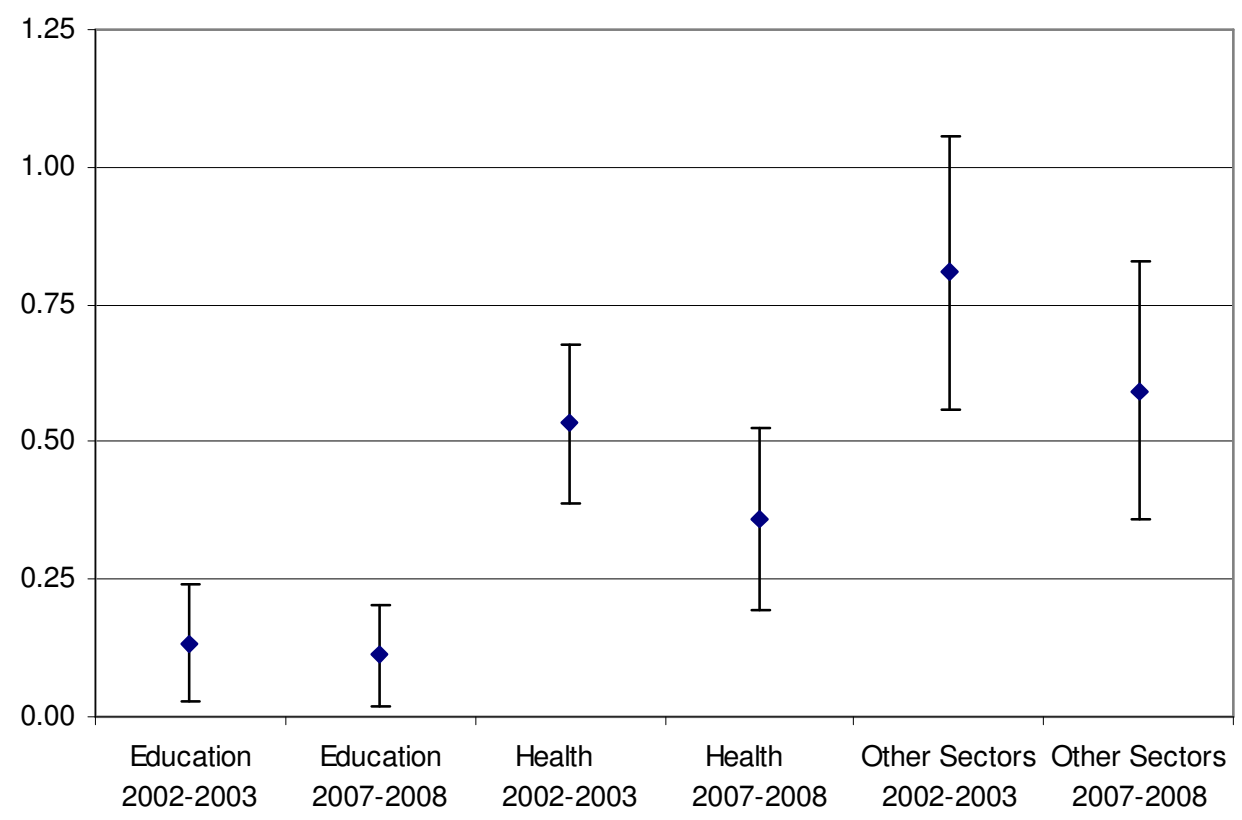


Figure 4. Estimated percentage change in per capita total transfers if representation is equalised, by LGA (ordered from greatest loss to largest gain)

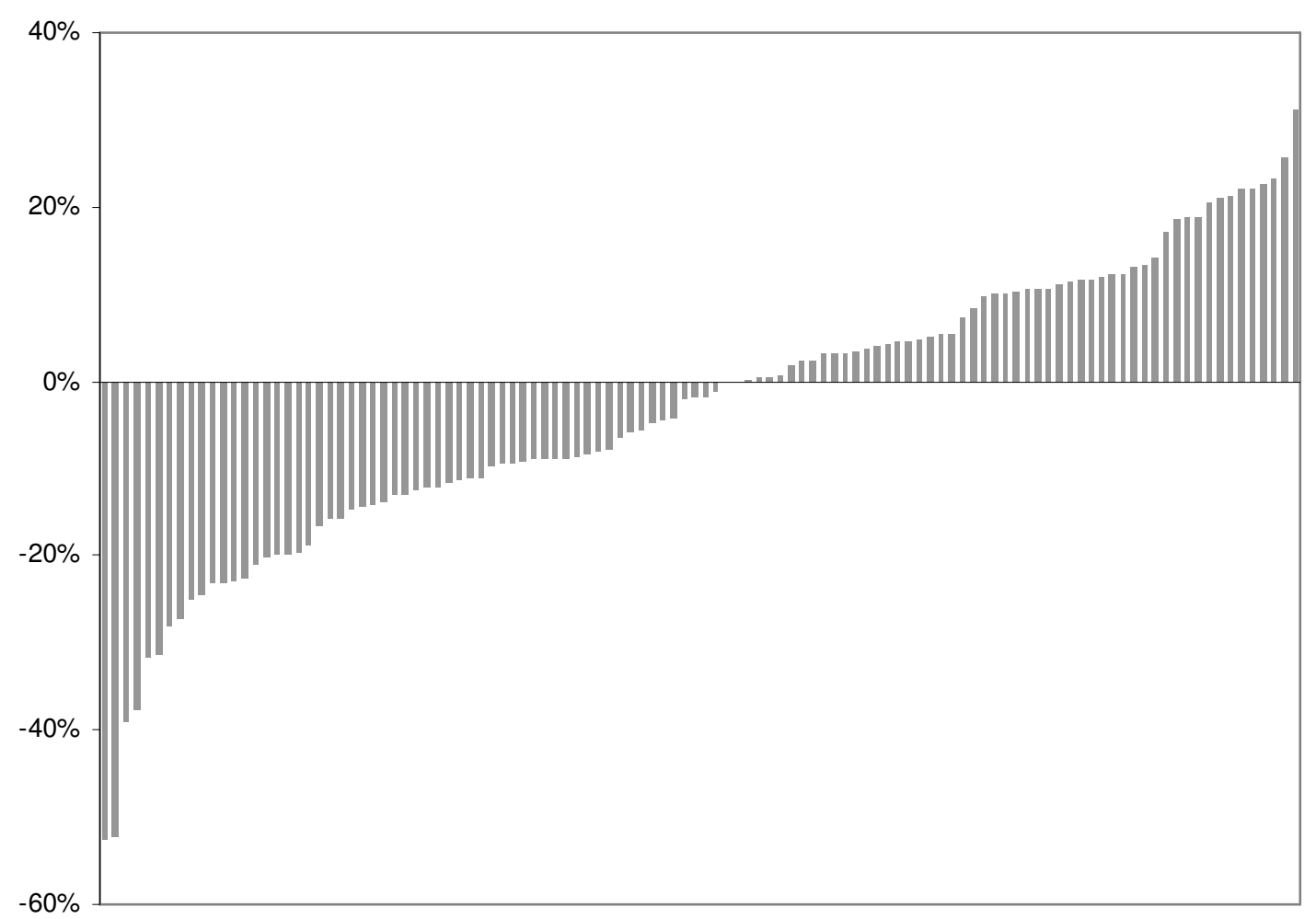

